\title{
Problems of quality of life of the population of coal-mining regions
}

\author{
Elena Kazantseva ${ }^{1, *}$, Galina Chistyakova $^{2}$, and Yury Kleshchevskiy ${ }^{1}$ \\ ${ }^{1}$ Kemerovo State University, 650000 Krasnaya Street 6, Kemerovo, Russia \\ ${ }^{2}$ Kemerovo State Medical University, 650029 Voroshilova Street 22a, Kemerovo, Russia
}

\begin{abstract}
Active research on the quality of life of the population began in the second half of the XX century in the United States. Such international organisations as the United Nations (UN), the World Health Organisation (WHO), the International Labour Organization (ILO), the Organisation for Economic Cooperation and Development (OECD) and others have been studying the problems of quality of life. The paper deals with the problems of the quality of life of the population of coal-mining regions. The main challenges include income inequality, low life expectancy, low employment, staff outflow, environmental problems, etc. The analysis of ways to solve the problems of improving the quality of life of the population of coal-mining regions is carried out.
\end{abstract}

\section{Introduction}

In the 1990s, UN experts developed a system of quality of life indicators, and specialists of the UN Development Program (UNDP) began to issue annual reports that published the human development index. According to UNDP Human Development Report 2020, the leading positions are occupied by Norway, Ireland, Switzerland, Hong Kong, and Iceland.

Many aspects of quality of life are assessed by a set of indicators for achieving the 17 UN Sustainable Development Goals that measure progress towards the Goals, both globally and nationally. Quite common are the Genuine Progress Index, the Index of Economic Well-Being, the Green Net National Product, the Physical Quality of Life Index, the Index of Social Health, the Index of Social Progress, etc.

The income level indicators are significant for evaluating the quality of life. The crisis caused by the COVID-19 pandemic led to their downfall. Credit Suisse Global Wealth Report 2020 states global wealth decrease. Latin America suffered significantly, where the decline in GDP caused by currency devaluation led to a $12.8 \%$ decline in total wealth in dollar terms. The pandemic has halted wealth growth in North America and caused losses in many regions, with the exception of China and India. Among the world's largest economies, the UK saw the biggest decline in wealth. Low-skilled workers, women, minorities, young people and small businesses were the most affected by the crisis. In the first half of 2020, the amount of welfare per adult in Russia fell by $10.7 \%$.

\footnotetext{
* Corresponding author: 9059655017@mail.ru
} 
However, income is not the only indicator that determines the quality of life. Experts note that in recent years, the gap between people's welfare and self-assessment of the quality of live has significantly increased. Although economic indicators remain important for assessing the state of the economy and the well-being of an individual, they are not sufficient to measure the quality of life. That is why priority is given to methods of quality of life research based on a combination of objective and subjective approaches.

Objective indicators include material resources (income level, living conditions, access to education and health services, environmental quality, job security, leisure conditions, etc.), while subjective ones take account of individual perception of the sufficiency of resources and personal assessment of the quality of life. The latter significantly depends on the priorities and needs of people and can include: physical, spiritual, mental and social health, religiosity and personal beliefs, emotional and cognitive spheres [1-3].

Over the past ten years, the OECD has been actively studying areas that affect the quality of life. The results of the research are the report "How is life?" and the index "Your Better Life Index". The object of this study is the most important aspects that affect people's lives and well-being: income, job security, housing conditions, health, the ratio of working and free time, education, social life, civic engagement, environment, security and life satisfaction. According to OECD Report "How's Life? 2020: Measuring Well-being", the leading positions in the rating are occupied by Norway, Australia, Iceland, Canada, and Denmark. Overall, Russians are less satisfied with their lives than the OECD average. When asked to rate their overall life satisfaction on a scale of 0 to 10 , Russians gave it an average of 5.8 points, which is lower than the OECD average of 6.5.

A new trend is the use of interactive tools for assessing the quality of life and attracting users to online surveys. Such approaches are typical for the OECD, the RBC and other structures that study quality of life issues.

Recently, studies have been updated to analyse the quality of life of various segments of the population, depending on the specialization of the region in which they live. The analysis of the quality of life of the population of coal-mining regions is important due to the growing problems of their development, increased outflow of population, low economic growth rates, etc.

The purpose of this research is to compare objective indicators of the quality of life of the population of the Kemerovo region - Kuzbass (Western Siberia, Russia) in dynamics and in comparison with the average Russian indicators, as well to identify the features of the quality of life of the population of coal-mining regions in foreign countries.

The work is based on the analysis of statistical materials of Federal State Statistics Service of the Russian Federation, OECD, UNDP, reports of research institutes, rating agencies, the results of research on the quality of life, including those published in Social Indicators Research: An International and Interdisciplinary Journal for Quality-of-Life Measurement.

The methodological basis for the study of the quality of life of the population was formed in the works of foreign and Russian scientists (J. K. Galbraith, M. Al-Qutop, H. Harrim], S. A. Ayvazyan, V. N. Bobkov, A. I. Tatarkin, G. M. Zarakovskij and others). The development of coal-mining and post-mining regions is the subject of interest for $\mathrm{P}$. Alves Dias, et al. [4]; P. Wirth, et al. [5]; E. Esposito, S. F. Abramson [6]; Q. Li, N. Stoeckl, et al. [7]; N. Ihsan, B. Aziz [8]; V. Zolotukhin, E. Stepantsova, et al. [9]; M. Cehlár, Ju. Janočko, et al. [10]; S. Zhironkin, M. Gasanov, et al. [11]; E. Kazantseva, O. Osokina, et al. [12]; E. Slesarenko, O. Sheveleva, et al. [13]; L. Noronha, S. Nair [14], and others. 


\section{Results and Discussion}

The quality of life of the population is one of the priorities for social and economic development. In the strategic planning documents of the federal, regional and municipal levels, the quality of life of the population is the object of managerial influence.

According to the Russian Federation's National Security Strategy, December 2015, improving the quality of life, strengthening the health of the population, and ensuring stable demographic development are the national interests for the long term. Ensuring national interests is carried out through the implementation of strategic national priorities, which include improving the quality of life of Russian citizens.

The National Security Strategy is the basic document of the country's strategic planning, defining the national interests and strategic national priorities of Russia, as well as goals, objectives and measures aimed at strengthening national security and ensuring the sustainable development of the country in the long run. Based on this, the national interests and strategic national priorities outlined in the National Security Strategy are embodied in the forecast and planning documents of the authorities at all levels.

The Russian Federation's National Development Goals until 2030 identify goals that are directly related to improving the quality of life of the population: preservation of the population, health and well-being of people; opportunities for self-realisation and talent development; a comfortable and safe living environment; decent, effective work and successful entrepreneurship; digital transformation. The goals provide for an increase in life expectancy in Russia to 78 years by 2030 , a decrease in the poverty level by half compared to that of 2017, and an increase in the proportion of citizens who are regularly engaged in physical education and sports to $70 \%$. By 2030, Russia should become one of the top ten countries in the world in terms of the quality of general education and the volume of research and development, including through the creation of an effective higher education system.

A unified methodology is important for assessing the quality of life of the population. In April 2021, at a joint meeting of the State Council Presidium and the Agency for Strategic Initiatives dedicated to social issues, V. V. Putin, the President of the Russian Federation, instructed to develop a methodology for rating the quality of life in the constituent entities of the Russian Federation. This will make it possible to conduct an annual assessment of the quality of life of the population of the regions and make timely management decisions.

In the Kemerovo region - Kuzbass, there is traditionally high interest in the problems of the quality of life of the population. More than 15 years ago, the Concept of the quality of life of the population of the Kemerovo region for 2005-2008 was adopted. The assessment of the quality of life was carried out using the method of integral assessment of the quality of life of the population in the relevant areas, developed by scientists of Kemerovo State University. Among the representatives of Kuzbass researchers of the problems of the quality of life of the population are V. A. Shabashev, E. A. Morozova, A.V. Mukhacheva, and others.

The mission of the Kemerovo Region - Kuzbass, formulated in the current Strategy for Social and Economic Development of the Kemerovo Region - Kuzbass until 2035, focuses on ensuring full and decent quality of life for Kuzbass residents and guests, effective implementation of Russia's national interests and priorities, as well as regional priorities of Kuzbass and all of Siberia.

Improving the quality of life of the population is sure to be a kind of eternal goal due to the increase in human needs. However, for resource-extracting regions, the issues of improving the quality of life are even more urgent because of consistently lower quality of life than the national average over a long period of time. 
Let us analyse the quantitative indicators characterizing the quality of life of the population of the Kemerovo region - Kuzbass in comparison with the average Russian indicators (Table 1), as well as the dynamics of indicators characterizing the quality of life of the population. The source of data analysed is Regions of Russia. Socio-economic indicators. 2020, the statistical digest of the Federal State Statistics Service of the Russian Federation.

Table 1. Selected indicators characterising the quality of life of the population of the Russian Federation and the Kemerovo Region - Kuzbass in 2019.

\begin{tabular}{|c|c|c|c|c|}
\hline Indicators & $\begin{array}{l}\text { The Russian } \\
\text { Federation }\end{array}$ & $\begin{array}{l}\text { The } \\
\text { Kemerovo } \\
\text { region - } \\
\text { Kuzbass }\end{array}$ & $\begin{array}{l}\text { Share of the } \\
\text { Kemerovo } \\
\text { region- } \\
\text { Kuzbass } \\
\text { in all-Russian } \\
\text { indicators, \% }\end{array}$ & $\begin{array}{l}\text { The rating of the } \\
\text { Kemerovo } \\
\text { region - } \\
\text { Kuzbass among } \\
\text { the subjects of } \\
\text { the Russian } \\
\text { Federation }\end{array}$ \\
\hline $\begin{array}{l}\text { Average per capita cash } \\
\text { income (per month), rub. }\end{array}$ & 35.247 & 24.886 & 70.6 & 63 \\
\hline $\begin{array}{l}\text { Average nominal accrued } \\
\text { salary of employees of } \\
\text { organisations (per month), rub. }\end{array}$ & 47.867 & 41.770 & 87.3 & 26 \\
\hline $\begin{array}{l}\text { Average amount of accrued } \\
\text { retirement benefits, rub. }\end{array}$ & 14.904 & 14.901 & 99.9 & 27 \\
\hline $\begin{array}{l}\text { Average consumer spending } \\
\text { per capita (per month), rub. }\end{array}$ & 28.470 & 18.885 & 66.3 & 71 \\
\hline Life expectancy at birth, years & 73.34 & 69.78 & 95.1 & 80 \\
\hline $\begin{array}{l}\text { Infant mortality, the number of } \\
\text { children who died before the } \\
\text { age of } 1 \text { year, per } 1000 \text { live } \\
\text { births }\end{array}$ & 4.9 & 6.2 & 126.5 & 73 \\
\hline $\begin{array}{l}\text { Mortality rate, the number of } \\
\text { deaths per } 1000 \text { population }\end{array}$ & 12.3 & 14.2 & 115.4 & 64 \\
\hline Unemployment rate, $\%$ & 4.6 & 5.5 & 119.6 & 59 \\
\hline $\begin{array}{l}\text { The total area of residential } \\
\text { premises per inhabitant on } \\
\text { average, sq. m }\end{array}$ & 26.3 & 25.4 & 96.6 & 57 \\
\hline $\begin{array}{l}\text { The number of students } \\
\text { enrolled in higher education } \\
\text { programs per } 10,000 \\
\text { population in the } 2019-2020 \\
\text { academic year }\end{array}$ & 277 & 176 & 63.5 & 65 \\
\hline
\end{tabular}


The statistical data demonstrate a significant "lag" in the values of indicators of the quality of life of Kuzbass population from the average Russian indicators. This applies to figures characterising the income of the population, the birth and mortality rates, the level of employment, etc. According to the above indicators, the Kemerovo region - Kuzbass is far from the leading position in the country. Thus, the region ranks $80^{\text {th }}$ in Life expectancy at birth. The mortality rate of the working-age population reaches critical values, the number of deaths per 100,000 people of the corresponding age accounts to 682 , exceeding the all-Russian indicator by $45.3 \%$. The mortality rates from neoplasms, including malignant ones (by 19.5\%), from diseases of the circulatory system $(14.7 \%)$ are also higher than the national ones. At the same time, the share of citizens following a healthy lifestyle is 3.5 times less than the national average.

A positive trend is the improvement of demographic indicators. Over the past 10 years, life expectancy at birth increased from 61.43 to 69.78 years, the number of children who died before the age of 1 year per 1000 live births decreased from 11.7 to 6.2 people, the number of deaths per 1000 people of the population declined from 18.9 to 14.2 people.

The region ranks $63^{\text {rd }}$ in the country in the value of the average per capita income of the population, while real incomes are growing at a lower rate (by 0.6\%). From 2010 to 2019, the growth of real incomes was observed both in the region and in the country only for six years out of ten. The average monthly nominal accrued salary of employees of organisations is $87.3 \%$ of the national average.

The state of income equality is somewhat better than the national average, as evidenced by the Gini coefficient (RF - 0.411, the Kemerovo region - Kuzbass - 0.350) and the fund ratio ( $R F-15.4$ times, the Kemerovo region - Kuzbass - 10 times). However, the population with incomes below the subsistence minimum, as a percentage of the total population of the constituent entity, is $10.6 \%$ higher than the national average (Russia $12.3 \%$, the Kemerovo region - Kuzbass $-13.6 \%$ ).

The results of the analysis of the quality of life of the population of the Kemerovo region - Kuzbass correlate with the results of the studies conducted by information and analytical agencies. So, in July 2020, the RBC Group has issued a rating "Best regions to live in", made use of the methodology of the credit rating agency "National Credit Ratings". The rating reflects the quality of life in the Russian regions and allows to compare the standard of living in different regions. It is calculated based on the level of consumer activity, housing affordability, the ability of the population to service loans, the level of official employment, the provision of the region with sports and cultural facilities, housing, climate, and a number of other indicators. The top five regions include St. Petersburg, Moscow, Belgorod, the Moscow region, and the Voronezh region. The Republic of Kalmykia, the Jewish Autonomous Region, the Republic of Altai, the Karachay-Cherkess Republic and the Republic of Tyva complete the ranking. The Kemerovo region took the $60^{\text {th }}$ place among all the subjects of the Russian Federation, scoring 2.42 points out of 7 possible points.

In 2020, the Financial University under the Government of the Russian Federation studied the quality of life in Russian cities with a population of more than 250 thousand people. The study was conducted in the following areas: the prevalence of "destructive" behaviour of the population - domestic violence and domestic injuries; dangerous driving, causing increased deaths on the roads, etc.; conflict nature of social relations, including appeals to the court and law enforcement agencies, conflicts with financial companies, etc.; interest in cultural values - theatres, exhibitions, museums, books, as well as the desire to get a good education for yourself and your children; the tendency to migrate in search of a better life; the level of income of the population, reflected through the interest in purchasing various goods and services; the state of urban infrastructure and the quality of urban 
management, which include: the state of roads and road facilities, the probability of getting into a traffic jam and a road accident; assessment of the quality of medical care for the population; quality of education; the work of housing and communal services to maintain the housing stock in good condition, as well as to improve the city; conditions for the creation and development of business; assessment of the quality of the work of local authorities. At the end of the study, a unified Quality of Life Index was calculated. The cities with the highest quality of life are Moscow, St. Petersburg, Grozny, Kaluga, Kazan, Yekaterinburg, Sevastopol, Sochi, Kaliningrad, and Naberezhnye Chelny. Novokuznetsk and Kemerovo, the cities of the Kemerovo region - Kuzbass, took only 52 and 72 places out of 75 , respectively.

It is worth mentioning that the problems of a lower quality of life of the population of coal-mining regions are typical not only for Russia. The researchers note that often after short-run positive effects of natural resource wealth, the region has to take measures to eliminate the negative consequences of coal mining. Thus, the results of the research made by E. Esposito and S. F. Abramson [6] show that post-mining regions of Europe are at least $10 \%$ poorer than other comparable regions within the same country. In addition, they have to deal with the consequences of the so-called "coal curse", which, to a greater extent, is identified as the curse of human capital, since coal mining has a large negative impact on the accumulation of human capital, especially in higher education. Coal-mining regions have fewer universities and $20 \%$ lower share of people with a university education. Moreover, people in these regions have a much more negative attitude towards formal education and are less future-oriented. Thus, the research results show that the extraction of natural resources without adequate investment in human capital does not lead to long-term prosperity, at least when it comes to coal in Europe.

Similar results of assessing the quality of life of the population of coal-mining regions were obtained in China [7]. The researchers conclude that increased coal production does not have an obvious effect on family income, but negatively influences air quality, water quality, and increases income inequality. The only positive effect associated with coal mining is the improvement of housing conditions.

The analysis of international experience in improving the quality of life of the population of coal-mining and post-mining regions [5] allows identifying the following main areas of activities being implemented: developing cultural and natural potential as well as tourism, diversifying the economy, and solving environmental problems. Such regions also face challenges related to the reclamation of mining sites and changing the image of the region. This will help to improve the social and economic development of the regions, counteract the emigration tendencies and, consequently, the brain drain. So, the researchers conclude that greater emphasis on health, education, and family time, rather than just economic production, is vital for improving the quality of life in the long term. Priority should be given to the social sectors in terms of budgetary resources and institutional development.

In the Kemerovo region - Kuzbass, considerable attention is currently paid to the problems of the quality of life of the population. One of the main priorities of the Strategy for Social and Economic Development of the Kemerovo Region - Kuzbass until 2035 is the priority "Kuzbass is the centre of high quality of life of the population". It implies the creation of the following centres: the centre for social services development; the centre for healthcare development; the centre for family development; the centre for culture and state national policy development; the centre for geriatric services provision; the centre for active leisure; the centre for the development of physical culture and sports in Kuzbass; the centre for providing the population with affordable and comfortable housing in Kuzbass. The issues of the quality of life of the population are reflected in other priorities of social and 
economic development of Kuzbass ("Kuzbass is the centre of professional excellence", "Kuzbass is the centre of decent work", and "Kuzbass is the centre of new competencies and jobs for green economy").

The regional authorities have developed specific measures aimed at the development of human capital and target indicators to assess the effectiveness of the measures taken. The Action plan for the Strategy implementation identifies the targets for each of the three development scenarios - conservative, targeted and optimistic (Table 2).

Table 2. Target indicators of the Strategy for Social and Economic Development of the Kemerovo Region - Kuzbass until 2035 characterising human capital development.

\begin{tabular}{|l|c|c|c|}
\hline \multirow{2}{*}{\multicolumn{1}{|c|}{ Indicator }} & \multicolumn{3}{|c|}{$\mathbf{2 0 3 5}$} \\
\cline { 2 - 4 } & $\begin{array}{c}\text { Conservative } \\
\text { scenario }\end{array}$ & $\begin{array}{c}\text { Targeted } \\
\text { scenario }\end{array}$ & $\begin{array}{c}\text { Optimistic } \\
\text { scenario }\end{array}$ \\
\hline $\begin{array}{l}\text { Population (in average annual } \\
\text { terms), thousand people }\end{array}$ & 2.720 & 2.750 & 2.755 \\
\hline Life expectancy, years & 81 & 81.1 & 82 \\
\hline $\begin{array}{l}\text { Average per capita cash } \\
\text { income, rub. }\end{array}$ & 90.269 & 120.286 & 121.000 \\
\hline $\begin{array}{l}\text { Average monthly nominal } \\
\text { accrued salary, rub. }\end{array}$ & 140.005 & 181.996 & 182.000 \\
\hline $\begin{array}{l}\text { The share of the population } \\
\text { with incomes below the } \\
\text { subsistence minimum, } \%\end{array}$ & 4 & 3.9 & 3.8 \\
\hline
\end{tabular}

By 2035, under any of the scenarios above, a significant improvement in the indicators characterising human capital development is expected. The basis for improving the quality of life of the population is solving environmental, economic and social problems, as well as changing the image of the region.

\section{Conclusion}

The problem of the quality of life of the population of coal-mining regions is relevant both for Russia and for most of coal-mining countries. The accumulated extensive international experience in improving the quality of life of the population of coal-mining and postmining regions allows Russia to develop comprehensive approaches to solving the problems of such territories.

The combination of efforts of federal and regional authorities will speed solving the problems related to the low standard of living of the population. Improving the methods of assessing the quality of life of the population and taking into account the results of researches conducted in this area will allow finding and studying the best practices and making new management decisions to improve the quality of life of the population. 


\section{References}

1. Z. Chen, G. Davey, Soc. Indic. Res., 91(2), 243 (2009)

2. R. Costanza, B. Fisher, S. Ali, C. Beer, L. Bond, R. Boumans, et al. Ecological Economics, 61(2), 267-276 (2007).

3. A. Self, Soc. Indic. Res., 130(1), 147-160 (2017).

4. P. Alves Dias, et al., EU coal regions: opportunities and challenges ahead (Publications Office of the European Union, Luxembourg, 2018)

5. P. Wirth, et al., Post-Mining Regions in Central Europe - Problems, Potentials, Possibilities (Oekom Verlag, Gesellschaft für ökologische Kommunikation mbH, München, 2012)

6. E. Esposito, S. F. Abramson, Econ. Growth, 26, 77-112 (2021)

7. Q. Li, N. Stoeckl, D. King, E. Gyuris, Soc. Indic. Res., 137, 895-921 (2018)

8. N. Ihsan, B. Aziz, Soc. Indic. Res., 142, 201-227 (2019)

9. V. Zolotukhin, E. Stepantsova, M. Kozyreva, A. Tarasenko, A. Stepantsov, E3S Web of Conferences, 15, 04014 (2017)

10. M. Cehlár, Ju. Janočko, Z. Šimková, T. Pavlik, M. Tyulenev, S. Zhironkin, and M. Gasanov, Resources, 8(1), 21 (2019)

11. S. Zhironkin, M. Gasanov, O. Zhironkina, EpSBS, III, 753-760 (2017)

12. E. Kazantseva, N. Osokina, G. Chistyakova, E3S Web of Conferences, 174, 04021 (2020)

13. E. Slesarenko, O. Sheveleva, N. Kudrevatykh, N. Vagina, E3S Web of Conferences, 174, 04002 (2020)

14. L. Noronha, S. Nair, Economic and Political Weekly, 40(1), $72-78$ (2005) 